\title{
PERBEDAAN KHASIAT ANTIBAKTERI BAHAN IRIGASI LARUTAN PROPOLIS DAN SODIUM HYPOCHLORITE TERHADAP BAKTERI Streptococcus viridans
}

\author{
Tabita Kusumawardhani*, Sukaton**, Achmad Sudirman** \\ *Mahasiswa strata 1 Fakultas Kedokteran Gigi Universitas Airlangga \\ **Staff pengajar Departemen Konservasi Gigi Fakultas Kedokteran Gigi Universitas Airlangga
}

\begin{abstract}
Background. Bacteria is main etiologycal factor of pulpo-periapical disease. Therefore, eliminating bacteria is the important part on root canal treatment. It can be obtained by using irrigation agent that has antibacterial effect and endodontic sterilization agent. Beside of its antibacterial effect, the ideal irrigation agent should has an ability to remove necrotic tissue and less toxic. Propolis is well known as a natural substain that has antibacterial effect and less toxicity. So, it has a potential use as irrigation agent compared with common root canal irrigation agent, sodium hypochloryte. Purpose. The aim of this study was to observed the difference of antibacterial effect between propolis solution and sodium hypochlorite. Method. Nine samples of Streptococcus viridans were prepared and each sample devided into three parts namely group $P$ (propolis solution), group $N$ (sodium hypochlorite), and control group $S$ (saline). Each group was treated with 0,01 cc agent of root canal irrigation, then was stored in incubator $37^{\circ} \mathrm{C}$ for 24 hours. After that, inhibition zone diameter of each group was observed.

Result. The average of inhibition zone diameters in sodium hypochlorite's group was 23,47 mm; in propolis solution's group was $18,70 \mathrm{~mm}$. There were significant difference of antibacterial effect between propolis solution and sodium hypochlorite, against Streptococcus viridans. Conclussion. Antibacterial effect of sodium hypochlorite is higher than propolis solution, but we should consider the potential use of natural agent-propolis solution as root canal irrigation due to its antibacterial effect.
\end{abstract}

Keywords : antibacterial effect, root canal irrigation, propolis, sodium hypochlorite, Streptococcus viridans.

\section{Pendahuluan}

Faktor utama pada inflamasi pulpa dan periodontitis apikalis adalah adanya bakteri. Hal tersebut telah diterima luas bahwa bakteri dan atau produknya adalah faktor etiologi utama pada inisiasi dan perkembangan penyakit ini. Oleh sebab itu, fokus perawatan saluran akar langsung ditujukan pada eliminasi dari bakteri dan substansinya pada saluran akar. Perawatan saluran akar meliputi pembersihan bakteri dan seluruh jaringan pulpa, pembentukan 
serta pengisian saluran akar (Gutmann, 2005).

Pembersihan saluran akar meliputi pembersihan bakteri, produk bakteri, jaringan pulpa yang nekrotik, debris organik, jaringan hidup, produk saliva, perdarahan dan kontaminasi lain. Cara untuk memperoleh saluran akar yang bersih dan steril adalah dengan menggunakan alat preparasi yang dapat dan menghaluskan dinding saluran akar untuk menghilangkan semua debris di dalamnya dan memakai bahan irigasi untuk mengeluarkan sisa bahan hasil preparasi berupa jaringan pulpa yang nekrotik dan serbuk dentin. Bahan irigasi yang ideal memiliki ketentuan antara lain adalah sebagai bahan pelarut debris atau jaringan nekrotik, tidak toksik, tegangan permukaan rendah, lubrikasi, membersihkan smear layer dan mempunyai efek sterilisasi (Walton, 2002).

Salah satu bahan irigasi adalah sodium hypochlorite (NaOCL) yang merupakan material proteolitik yang telah digunakan sejak 85 tahun yang lalu (Farren ST, 2008). Penggunaan sodium hypochlorite sebagai bahan kimia setelah pengambilan isi saluran akar secara mekanis merupakan suatu prosedur yang dilakukan dalam perawatan endodontik. Sodium hypochlorite beraktivitas pada jaringan nekrotik dan jaringan vital serta sifat antibakteri dan sifat lubrikasi yang dimilikinya menjadikan sodium hypochlorite sebagai pilihan bahan irigasi saluran akar pada perawatan endodontik (Mehra P et al, 2000 ; Wesselink P and Bergenholtz G, 2003). Banyak klinisi lebih memilih konsentrasi 2,5\% untuk bahan irigasi ini karena dianggap cukup efektif dan aman untuk pasien dan dokter gigi (Walton 2002). Sodium hypochlorite dapat merusak jaringan periapikal jika dipakai dalam konsentrasi tinggi dan penggunaan yang tidak hati-hati. Oleh karena itu pemakainnya harus sangat hati-hati dan perlu ada alternatif lain yang lebih aman (Widjastuti, 2006).

Pemanfaatan bahan alam sebagai obat tradisional di Indonesia akhir-akhir ini meningkat, bahkan beberapa bahan alam telah diproduksi secara fabrikasi dalam skala besar. Penggunaan obat tradisional dinilai memiliki efek samping yang lebih kecil dibandingkan dengan obat yang berasal dari bahan kimia (Aulia, 2008). Pemanfaatan bahan alam yang dapat digunakan adalah dari tumbuhan maupun hewan, salah satunya adalah lebah. Lebah menghasilkan beberapa produk seperti madu, royal jeli, polen, dan propolis (Jaya et al, 2005). 
Propolis adalah suatu material resin yang dikumpulkan lebah dari pucuk-pucuk pepohonan. Lebah membawa resin tersebut kembali ke sarang dan menggunakannya untuk memproduksi substansi seperti lem yang akan dipakai untuk mengisi celah dan menutup sarangnya. Propolis tersusun dari resin $(55 \%)$, minyak esensial dan wax $(30 \%)$ bercampur dengan produk sekresi saliva dari lebah dan pollen (5\%) dan substansi lainnya (10\%) yang tersusun dari asam amino, mineral, ethanol (alkohol), vitamin A, B kompleks, dan vitamin E. Beberapa ilmuwan menggunakan propolis untuk pengobatan karena mampu mengurangi pembengkakan, meringankan indurasi, meringankan nyeri otot dan menyembuhkan luka. Propolis telah terbukti memiliki sifat antibakteri, antivirus, anti jamur, antiinflamasi dan reaksi anestesi. Dalam Kedokteran gigi telah digunakan untuk penyembuhan luka operasi, pulp capping direk dan indirek, mengurangi hipersensitivitas dentin, perawatan saluran akar yang terinfeksi, dan periodontitis (AlQathami, 2003). Oleh karena itu peneliti ingin meneliti perbedaan khasiat antibakteri perbedaan khasiat antibakteri pada larutan propolis dan sodium hypochlorite terhadap bakteri Streptococcus viridans.

\begin{abstract}
Alat dan Metode Penelitian
Penelitian yang dilakukan merupakan penelitian eksperimental laboratoris dengan menggunakan rancangan post test control group design.
\end{abstract}

Propolis yang digunakan dalam penelitian ini adalah propolis komersial Hezzel Farm Propolis 500 mg dalam bentuk kapsul yang dilarutkan dengan pelarut 120 $\mathrm{ml}$ aquades hangat sehingga mencapai konsentrasi $0,42 \%$ (al qatami). Sodium Hypochlorite 2,5\% dan salin (kontrol) sudah tersedia dalam sediaan pro analisis.

Stok bakteri Streptococcus viridans yang didapatkan dari swab rongga mulut manusia dan kemudian dikultur, dimasukkan dalam tabung reaksi yang telah diisi media BHIB kemudian diinkubasi dengan suhu $37^{0} \mathrm{C}$ selama 24 jam. Setelah itu, media tersebut ditipiskan dengan mengambil 0,05 cc BHIB menggunakan mikropipet kemudian dimasukkan pada tabung reaksi kedua yang berisi BHIB steril 5 cc. Langkah yang sama dilakukan dari tabung reaksi kedua ke tabung reaksi ketiga yang juga berisi 5cc BHIB steril. Dari tabung reaksi ketiga, diambil 0,05 cc dan diratakan pada 
media Mueller Hinton Agar dalam petridish. Dengan demikian, diperolehlah media padat dengan kultur Streptococcus viridans.

Petridish yang berisi kultur disiapkan sesuai jumlah besar sampel yang ditentukan yaitu sembilan sampel. Setiap petridish dibagi menjadi tiga dan diberi tanda garis dengan spidol. Bagian pertama untuk larutan propolis $0,42 \%$, bagian kedua untuk sodium hypochlorite $2,5 \%$, dan bagian ketiga untuk salin $0,9 \%$ sebagai kontrol negatif.

Sejumlah dua puluh tujuh kertas hisap yang sudah ditentukan disiapkan dalam glass lab dan ditetesi masing-masing $0,01 \mathrm{cc}$ salah satu bahan uji dengan jumlah yang sama untuk setiap bahan uji. Setelah itu, kertas hisap yang sudah basah dimasukkan dalam kultur pada media Mueller Hinton Agar sesuai pembagian tempat yang sudah dilakukan sebelumnya.

Setelah semua kertas hisap sudah dimasukkan dalam petridish tertutup, seluruh sampel tersebut dimasukkan dalam inkubator bersuhu $37^{0} \mathrm{C}$ selama 24 jam.

Parameter yang digunakan untuk mengetahui kekuatan antibakteri dari masing-masing bahan uji adalah diameter zona hambat yang dihasilkan. Zona hambat pada petridish tampak transparan mengelilingi kertas hisap dan diameternya diukur sebanyak tiga kali secara vertikal, horizontal dan diagonal dengan penggaris yang memiliki ketelitian $1 \mathrm{~mm}$, kemudian diambil rata-rata dari ketiga hasil pengukuran.

\section{Hasil}

Berdasarkan hasil pengamatan dan pengukuran diameter zona hambat yang dihasilkan masing-masing bahan irigasi, maka diperoleh hasil bahwa rata-rata diameter zona hambat yang dihasilkan larutan propolis terhadap bakteri Streptococcus viridans adalah $18,70 \mathrm{~mm}$ dan rata-rata diameter zona hambat yang dihasilkan sodium hypochlorite terhadap bakteri Streptococcus viridans adalah 23,47 mm. Pada kelompok kontrol dengan bahan irigasi salin tidak didapatkan adanya zona hambat terhadap bakteri Streptococcus viridans.

Selanjutnya dilakukan uji statistik Independent Sample $t$ Test untuk melihat adanya perbedaan antar sampel.

Tabel 5.2 Uji statistik menggunakan Independent Sample t Test

\begin{tabular}{|l|c|c|}
\hline Uji statistik & $\mathrm{t}$ & Sig. (2-tailed) \\
\hline $\begin{array}{l}\text { Independent Sampel } t \\
\text { Test }\end{array}$ & 2,746 & $0,000^{*}$ \\
\hline
\end{tabular}


Hipotesis :

$$
\begin{aligned}
\mathrm{H}_{\mathrm{o}}= & \text { Kedua rata-rata populasi adalah } \\
& \text { identik ( rata-rata populasi zona } \\
& \text { hambat Larutan Propolis dan Sodium } \\
& \text { Hypochlorite adalah sama). } \\
\mathrm{H}_{1}= & \text { Kedua rata-rata populasi adalah tidak } \\
& \text { identik ( rata-rata populasi zona } \\
& \text { hambat Larutan Propolis dan Sodium } \\
& \text { Hypochlorite adalah berbeda). }
\end{aligned}
$$

Berdasarkan hasil yang diperoleh dengan uji Independent Sample $t$ Test, terlihat bahwa $\mathrm{t}$ hitung yang digunakan untuk zona hambat adalah 2,746 dengan probabilitas 0,017. Untuk uji dua sisi, probabilitas menjadi $0,017 / 2=0,0085$. Oleh karena $0.0085<0,025$, maka $\mathrm{H}_{\mathrm{o}}$ ditolak. Rata-rata diameter zona hambat larutan propolis berbeda signifikan dengan sodium hypochlorite; jika dilihat dari rata-rata kedua kelompok, diameter zona hambat yang dihasilkan sodium hypochlorite lebih besar dari larutan propolis.

\section{Pembahasan}

Untuk mengetahui perbedaan khasiat antibakteri larutan propolis dan sodium hypochlorite, digunakan diameter zona hambat masing - masing bahan irigasi tersebut sebagai indikator yang akan dibandingkan juga dengan salin sebagai kontrol negatif. Hasil penghitungan menggunakan Independent Sample $t$ Test menunjukkan adanya perbedaan khasiat antibakteri antara larutan propolis dan sodium hypochlorite terhadap bakteri Streptococcus viridans dengan hasil yang lebih tinggi pada sodium hypochlorite.

Salin yang digunakan sebagai kontrol negatif tidak memiliki zona hambat karena zat tersebut tidak memiliki sifat antibakteri. Salin digunakan sebagai bahan irigasi karena sifatnya yang sama dengan cairan tubuh sehingga aman untuk jaringan saat terjadi interaksi. Tidak adanya zona hambat pada daerah kertas hisap yang ditetesi normal salin juga membuktikan bahwa adanya zona hambat pada kedua bahan irigasi lainnya yang digunakan yaitu larutan propolis dan sodium hypochlorite adalah murni karena efek antibakteri yang dihasilkan keduanya.

Seperti diketahui larutan propolis dan sodium hypochlorite memiliki perbedaan pada bahan aktif antibakteri dan mekanisme 
dalam menghambat pertumbuhan bakteri sehingga membuat efek antibakterinya juga berbeda terhadap Streptococcus viridans. Bahan aktif dari larutan propolis adalah flavonoid merupakan zat antibakteri yang terdapat dalam tumbuhan. Flavonoid berfungsi sebagai antibakteri dengan cara membentuk senyawa kompleks terhadap protein ekstraseluler yang mengganggu integritas membran sel bakteri dan merupakan senyawa fenol sementara senyawa fenol dapat bersifat koagulator protein (Juliantina, 2009). Fenol yang merupakan derivat alkohol memiliki sifat mudah menguap dan efek antibakteri yang dihasilkan menjadi lebih singkat. Pada sodium hypochlorite, bahan aktifnya adalah klorin yang sangat stabil dalam bentuk cair, desinfektan tingkat tinggi sehingga memiliki efek antibakteri yang lebih baik (Martindale, 2009). Mekanisme antibakteri pada kedua bahan uji pada dasarnya sama-sama merusak integritas membran sitoplasma sehingga terjadi kebocoran sitoplasma dan menyebabkan sel lisis walaupun mekanisme secara detailnya berbeda.

Zat yang terkandung di dalam larutan propolis selain flavonoid cukup kompleks yaitu vitamin, terutama vitamin B-Komplex dan juga mengandung vitamin $\mathrm{C}, \mathrm{E}$ dan biotin, mineral/unsur kalsium, zat besi, zink, copper, chrome silizium, vanadium dan mangan dan asam amino essensial (Sabir, 2005). Berbagai macam kandungan propolis yang kompleks inilah diduga menjadi penyebab berkurangnya khasiat dari flavonoid sebagai antibakteri. Berbeda dengan sodium hypochlorite yang hanya terdiri dari sedikit unsur kimia yaitu natrium, oksida dan klorin yang memiliki daya antibakteri yang kuat, sehingga mampu memberikan efek antibakteri maksimal (Martindale, 2009).

Namun demikian, sodium hypochlorite merupakan bahan kimia yang mempunyai efek samping untuk jaringan terutama rongga mulut yaitu dapat menyebabkan rasa terbakar, nyeri dan inflamasi pada jaringan lunak sekitar yang kemungkinan bisa tersebar dari pemakaian yang tidak hati - hati, perdarahan dari saluran akar, perdarahan interstitial pada kult, iritasi, dan parastesi (Martindale 2009).

Penggunaan larutan propolis sebagai bahan irigasi saluran akar gigi patut diperhitungkan dan lebih dikembangkan walaupun efek antibakteri yang dihasilkan dari penelitian ini lebih kecil dibandingkan dengan efek antibakteri yang dimiliki sodium hypochlorite. Pertimbangan ini 
didasarkan pada propolis yang merupakan bahan alami dari alam, produk lebah yang memiliki berbagai macam khasiat dengan tidak ada laporan mengenai efek samping terhadap jaringan. Dalam Kedokteran gigi, propolis telah digunakan untuk penyembuhan luka operasi, pulp capping direk dan indirek, mengurangi hipersensitivitas dentin, perawatan saluran akar yang terinfeksi, dan periodontitis (AlQathami, 2003). Penggunaan larutan propolis sebagai alternatif perawatan endodontik juga direkomendasikan karena memiliki potensi iritasi yang rendah dan memiliki efek antibakteri yang sebanding dengan sodium hypochlorite terhadap bakteri mix (Silva SB, 2003 ; Al-Qathami, 2003)

\section{Daftar Pustaka}

1. Al-Qathami. 2003. Comparison of sodium hypochlorite, propolis and saline as root canal irrigants: A pilot study. Saudi Dental Journal Vol 5 no.2. Accessed on January ,2010.

2. Aulia, Ilmi. 2008. Uji Aktivitas Antibakteri Fraksil Etil Asetat Ekstrak Etanolik Daun Arbenan Tehadap Staphylococcus aureus dan Pseudomonas aeruginosa Multiresisten Antibiotik beserta Profil Kromatografi Lapis Tipisnya. Surakarta, Universitas Muhammadiyah. hal : 1-2.

3. Farren ST, Sadoff Rs, Penna KJ. Sodium Hypochlorite Chemical Burn. New York State Dent Journal 2008 ; 74 (1) pp : 61-2.

4. Guttman, J.L. 1992. Problem Solving in Endodontics, Prevention, identification and management. 2nd ed. St Louis: Mosby Year Book. p: 77-86.
5. Jaya et al. 2005. Pengaruh Pemberian Ekstrak Propolis terhadap Sistem Kekebalan Seluler Pada Tikus Putih Strai Wistar. Diambil dari : http://firmanjaya.files.wordpress.com/2008/08/my -journal-new.pdf. Diakses pada Desember , 2009.

6. Juliantina, et al. 2009. Manfaat Sirih Merah Sebagai Agen Antibakterial Terhadap Bakteri Gram Positif dan Gram Negatif. Diambil dari : http://journal.uii.ac.id/index.php/

JKKI/article/viewFile/543/467. Diakses pada Desember, 2009.

7. Martindale. 2009. The Complete Drug Reference. Thirty-sixth edition. Chicago; Pharmaceutical Press. p: 1661-1662

8. Mehra P, Clancy C, Wu J. Case Report : Formation of a Hematoma During Endodontic Therapy. J Am Dent Assoc 2000 ; 131 pp : 67-71. Accessed on December 2010.

9. Sabir, Ardo. 2005. Aktivitas antibakteri flavonoid propolis Trigona $s p$ terhadap bakteri Streptococcus mutan (in vitro). Majalah kedokteran Gigi (Dent. J). Vol. 38, No. 3 JuliSeptember. hal : 135-141.

10. Silva FB, Almeida JM, Sousa SMG. 2004. Natural medicaments in endodontics - a comparative study of the anti-inflammatory action. Braz Oral Res 2004;18(2). pp: 174-9.

11. Walton, R and Torabinejad, M. 2002. Principles and Practice of Endodontics. 3rd ed. Philadelphia: W.B. Saunders Co. p: 207-292.

12. Wesselink P, Bergenholtz G. Treatment of the Necrotic Pulp. In: Bergenholtz G, HorstedBindslev P, Reit C,eds . Textbook of Endodontology. 1st ed. Oxford : Blackwell 2003. pp : 156-73. Accessed on December 2010.

13. Widjastuti, Ira. 2006. Perbedaan Daya Hambat terhadap Pertumbuhan Mikroorganisme Saluran Akar Gigi Nekrose antara Bahan Irigasi $\mathrm{H}_{2} \mathrm{O}_{2} 3 \%$, NaOCL 2,5\%, dan Chlorhaxidine Gluconate $0,2 \%$. Surabaya,Universitas Airlangga. hal : 2-3 